\title{
Aircraft measurements of carbon dioxide and methane for the calibration of ground-based high-resolution Fourier Transform Spectrometers and a comparison to GOSAT data measured over Tsukuba and Moshiri
}

\author{
T. Tanaka ${ }^{1, *}$, Y. Miyamoto ${ }^{1, *}$, I. Morino ${ }^{1}$, T. Machida ${ }^{1}$, T. Nagahama ${ }^{2}$, Y. Sawa ${ }^{3}$, H. Matsueda ${ }^{3}$, D. Wunch $^{4}$, \\ S. Kawakami ${ }^{5}$, and O. Uchino ${ }^{1}$ \\ ${ }^{1}$ National Institute for Environmental Studies, 16-2 Onogawa, Tsukuba, Ibaraki, 305-8506, Japan \\ ${ }^{2}$ Solar-Terrestrial Environment Laboratory, Nagoya University, Furo-cho, Chikusa-ku, Nagoya, 464-8601, Japan \\ ${ }^{3}$ Meteorological Research Institute, 1-1 Nagamine, Tsukuba, Ibaraki, 305-0052, Japan \\ ${ }^{4}$ California Institute of Technology, Pasadena, CA, 91125-2100, USA \\ ${ }^{5}$ Japan Aerospace Exploration Agency Earth Observation Research Center, 2-1-1 Sengen, Tsukuba, Ibaraki, 305-8505, Japan \\ *now at: Japan Aerospace Exploration Agency Earth Observation Research Center, 2-1-1 Sengen, Tsukuba, \\ Ibaraki, 305-8505, Japan \\ ** now at: Graduate School of Natural Science and Technology, Okayama University, 3-1-1 Tsushima-naka kita-ku, \\ Okayama, 700-8530, Japan
}

Correspondence to: T. Tanaka (tanaka.tomoaki@jaxa.jp)

Received: 28 December 2011 - Published in Atmos. Meas. Tech. Discuss.: 23 February 2012

Revised: 20 June 2012 - Accepted: 6 July 2012 - Published: 20 August 2012

\begin{abstract}
Aircraft measurements of carbon dioxide and methane over Tsukuba $\left(36.05^{\circ} \mathrm{N}, 140.12^{\circ} \mathrm{E}\right)$ (February 2010) and Moshiri $\left(44.36^{\circ} \mathrm{N}, 142.26^{\circ} \mathrm{E}\right.$ ) (August 2009) were made to calibrate ground-based high-resolution Fourier Transform Spectrometers (g-b FTSs) and to compare with the Greenhouse gases Observing SATellite (GOSAT). The aircraft measurements over Tsukuba in February 2010 were successful in synchronizing with both the g-b FTS and GOSAT for the first time. Airborne in situ and flask-sampling instruments were mounted on the aircraft, and measurements were carried out between altitudes of 0.5 and $7 \mathrm{~km}$ to obtain vertical profiles of carbon dioxide $\left(\mathrm{CO}_{2}\right)$, methane $\left(\mathrm{CH}_{4}\right)$, and other gaseous species.

By comparing the g-b FTS measurements with the airborne measurements, the column-averaged dry air mole fractions of $\mathrm{CO}_{2}\left(\mathrm{X}_{\mathrm{CO}_{2}}\right)$ and $\mathrm{CH}_{4}\left(\mathrm{X}_{\mathrm{CH}_{4}}\right)$ retrieved from the g-b FTS measurements at Tsukuba were biased low by $0.33 \pm 0.11 \%$ for $\mathrm{X}_{\mathrm{CO}_{2}}$ and $0.69 \pm 0.29 \%$ for $\mathrm{X}_{\mathrm{CH}_{4}}$.

The g-b FTS values at Moshiri were biased low by $1.24 \%$ for $\mathrm{X}_{\mathrm{CO}_{2}}$ and $2.11 \%$ for $\mathrm{X}_{\mathrm{CH}_{4}}$. The GOSAT data show biases that are $3.1 \% \pm 1.7 \%$ lower for $\mathrm{X}_{\mathrm{CO}_{2}}$ and $2.5 \% \pm 0.8 \%$
\end{abstract}

lower for $\mathrm{X}_{\mathrm{CH}_{4}}$ than the aircraft measurements obtained over Tsukuba.

\section{Introduction}

Global warming by greenhouse gases is one of the most important environmental issues of our time. Atmospheric concentrations of carbon dioxide $\left(\mathrm{CO}_{2}\right)$, methane $\left(\mathrm{CH}_{4}\right)$, and nitrous oxide $\left(\mathrm{N}_{2} \mathrm{O}\right)$ have been increasing since the beginning of the industrial era as a result of human activities. $\mathrm{CO}_{2}$, in particular, is an important greenhouse gas, second only to water vapor, and the global-averaged concentration of atmospheric $\mathrm{CO}_{2}$ increased from $280 \mathrm{ppm}$ in the pre-industrial era to $389.0 \mathrm{ppm}$ in 2010 (World Meteorological Organization Greenhouse Gas Bulletin, 2011). Increases in these greenhouse gases enhance a radiative forcing of the atmosphere and affect global climate change. An accurate prediction of the $\mathrm{CO}_{2}$ concentration requires measurements for the quantification of the distribution and variability of $\mathrm{CO}_{2}$ sources and sinks. Ground stations and tall

Published by Copernicus Publications on behalf of the European Geosciences Union. 
towers with flask-sampling and/or in situ instruments using Non-Dispersive InfraRed (NDIR) analyzers and cavity ringdown spectroscopy (Inoue and Matsueda, 2001; Winderlich et al., 2010) currently measure atmospheric $\mathrm{CO}_{2}$ with high precision. In addition, ship- and aircraft-based measurements have been carried out, though less frequently. These measurements are precise but sparse, especially in Africa and South America. This sparseness causes large uncertainties in current estimates of the $\mathrm{CO}_{2}$ sources and sinks (Gurney et al., 2001). Rayner and O'Brien (2001) established the required precision of monthly averaged column data better than $2.5 \mathrm{ppm}$ for the total of atmospheric $\mathrm{CO}_{2}$ data to be useful for reducing the uncertainties in regional $\left(8^{\circ} \times 10^{\circ}\right.$ footprint $)$ $\mathrm{CO}_{2}$ source and sink estimations. The feasibility of a global measurement of $\mathrm{CO}_{2}$ in the near-infrared region from space has been explored in the past (O'Brien and Rayner, 2002; Mao and Kawa, 2004). The authors determined that spacebased measurements are one of the most effective tools for $\mathrm{CO}_{2}$ source and sink estimations because of the wide spacial coverage they offer around the globe. The Greenhouse gases Observing SATellite (GOSAT) was developed jointly by the Japanese Ministry of the Environment (MOE), the National Institute for Environmental Studies (NIES), and the Japan Aerospace Exploration Agency (JAXA) to measure concentrations of $\mathrm{CO}_{2}$ and $\mathrm{CH}_{4}$ from space. After GOSAT was launched, it was placed in a sun-synchronous orbit at a 666-km altitude with a 3-day revisit time of around 12:50 LT (local time) (Yokota et al., 2009). The instruments onboard GOSAT are the Thermal And Near-infrared Sensor for carbon Observation Fourier Transform Spectrometer (TANSOFTS) and the TANSO Cloud and Aerosol Imager (TANSOCAI) (Kuze et al., 2009). TANSO-FTS measures the solar radiation reflected from the ground at three Short Wavelength InfraRed (SWIR) bands $(0.76,1.6$, and $2.0 \mu \mathrm{m})$ and the emission from the ground and atmosphere at the wide Thermal InfraRed (TIR) band (5.5-14.3 $\mu \mathrm{m})$ with a resolution of $0.2 \mathrm{~cm}^{-1}$.

Space-based instruments have to be validated using other measurements, such as in situ or sampling measurements by aircraft and remote sensing measurements by ground-based high-resolution Fourier Transform Spectrometers ((g-b) FTS). Measuring direct sunlight with a g-b FTS is one of the most precise remote sensing techniques to derive the total column of atmospheric $\mathrm{CO}_{2}$ under clear sky conditions (Washenfelder et al., 2003; Ohyama et al., 2009; Messerschmidt et al., 2010, 2011). The g-b FTS at Tsukuba is part of the Total Carbon Column Observing Network (TCCON) (Wunch et al., 2011) and is used to validate $\mathrm{X}_{\mathrm{CO}_{2}}$ and $\mathrm{X}_{\mathrm{CH}_{4}}$ retrieved from the GOSAT observation. The total column from space is directly validated by the total column measurement from the ground (i.e., the TCCON FTS instruments).

For this reason the g-b FTS at Tsukuba must be calibrated against an instrument with high precision and accuracy obtained independently. For this work, we carried out aircraft

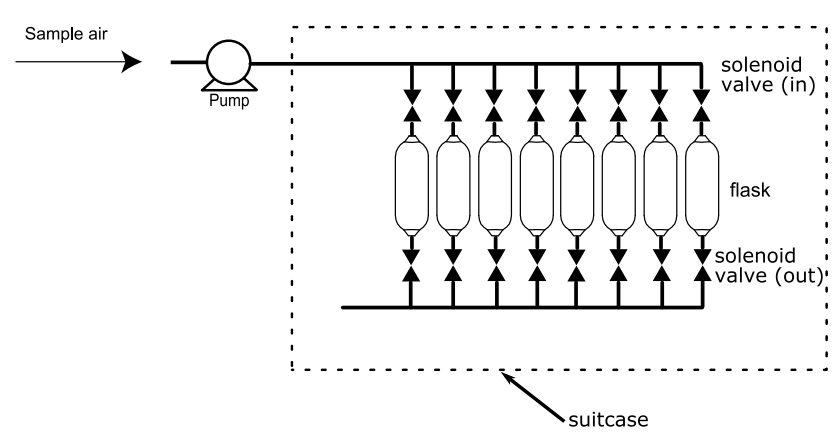

Fig. 1. Schematic diagram of the hand-operated air-sampling equipment (HSE). The whole system is in a suitcase equipped with cushioning materials to reduce shocks by airframe vibrations.

measurements over Tsukuba and Moshiri. The purpose of these aircraft measurements was to calibrate the g-b FTS over Tsukuba and Moshiri and validate the GOSAT data. We installed hand-operated air-sampling equipment (HSE) and continuous $\mathrm{CO}_{2}$ measuring equipment (CME) on the aircraft in order to measure vertical profiles of $\mathrm{CO}_{2}$ and $\mathrm{CH}_{4}$. The column-averaged dry air mole fractions of $\mathrm{CO}_{2}\left(\mathrm{X}_{\mathrm{CO}_{2}}\right)$ and $\mathrm{CH}_{4}\left(\mathrm{X}_{\mathrm{CH}_{4}}\right)$ were calculated from the aircraft measurements to compare with those derived from the g-b FTSs and GOSAT. We describe the measurement instruments onboard the aircraft in Sect. 2. The details of the aircraft measurements and the ground sites are described in Sect. 3. The calculation of $\mathrm{X}_{\mathrm{CO}_{2}}$ and $\mathrm{X}_{\mathrm{CH}_{4}}$ from the aircraft profiles is presented in Sect. 4, and the results of the g-b FTS and GOSAT comparison with the aircraft measurements are discussed in Sect. 5 .

\section{Aircraft and instruments}

\subsection{Aircraft}

The Beechcraft King Air 200T, operated by Diamond Air Service Inc., is a twin-turboprop aircraft with a pressurized cabin. We installed the $\mathrm{CME}$ for continuous $\mathrm{CO}_{2}$ measurement and the HSE for $\mathrm{CO}_{2}, \mathrm{CH}_{4}$, and other gases. Typical durations were $1.7-2.3 \mathrm{~h}$ while spiral descent flights between $7 \mathrm{~km}$ and $0.5 \mathrm{~km}$ were carried out. The position (latitude, longitude, and ellipsoid height) of the aircraft was monitored by GPS, and information on the outside temperature, static pressure, and ground speed was provided by the aircraft's instruments.

\subsection{Hand-operated air-sampling equipment (HSE)}

The HSE is composed of Pyrex glass flasks and solenoid valves in a suitcase equipped with cushioning materials to reduce shocks by airplane vibrations. Figure 1 shows a schematic diagram of the HSE instrument. Eight 750-ml glass flasks are enclosed in the case. The solenoid valves 


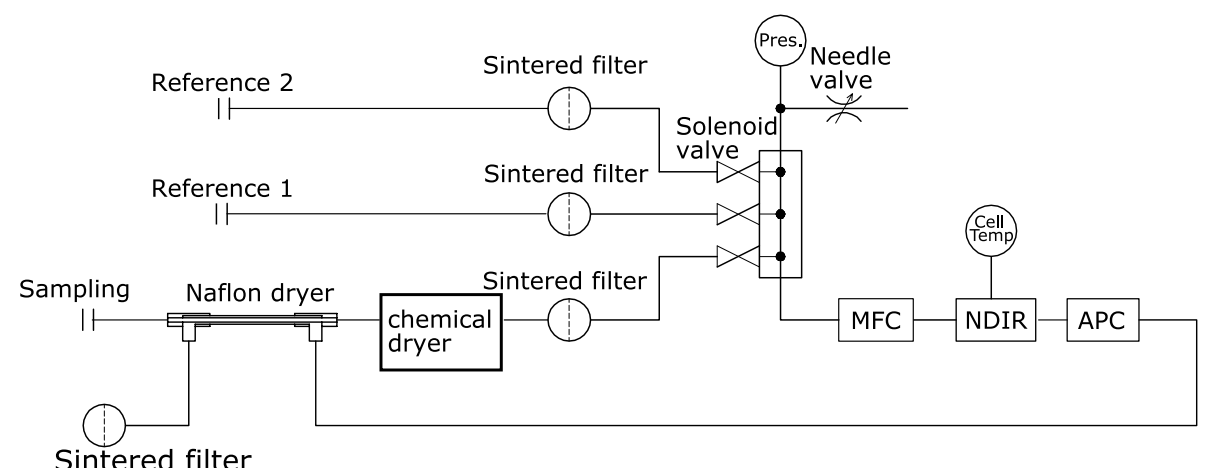

Fig. 2. Schematic diagram of the continuous $\mathrm{CO}_{2}$ measuring equipment (CME). The flow rate is controlled by a mass flow controller (MFC), and the absolute pressure of the Non-Dispersive InfraRed (NDIR) cell is regulated by an automatic pressure controller (APC).

(SMC, SYJ314M-6LZ) were attached to both ends of the flask and actuated by high-pressure $\mathrm{N}_{2}$ gas from a gas cylinder. An air inlet port was placed in a front-facing position at the top fuselage of the aircraft, and a stainless steel tube, used to flow air to the instruments, was placed in the aircraft. A diaphragm pump (Gast Manufacturing, Inc., MAA-P108HB) was connected to the stainless steel tube to pressurize sample air into the flask. The procedure of sampling air in the atmosphere was done as follows: Opening and closing actions for in/out solenoid valves at both ends of the flask were made by a valve controller. Sampling was started when the aircraft reached the desired altitude. First, both solenoid valves were left open to exchange the air inside the flask for $60 \mathrm{~s}$. Then the solenoid valve (out) was closed to pressurize to $0.2 \mathrm{MPa}$ in the flask for $45 \mathrm{~s}$. Finally, the solenoid valve (in) was closed. After the flight, the HSE was unloaded from the aircraft and transported to NIES for high-precision analysis of the volume mixing ratios (VMRs) of $\mathrm{CO}_{2}, \mathrm{CH}_{4}, \mathrm{CO}, \mathrm{H}_{2}$, $\mathrm{N}_{2} \mathrm{O}$, and $\mathrm{SF}_{6}$. The $\mathrm{CO}_{2}$ concentration was analyzed with a NDIR analyzer (LI-COR, either LI-6252 or LI-6262), and a gas chromatograph equipped with a flame ionization detector (GC-FID; Agilent Technologies, HP-5890) was used to analyze $\mathrm{CH}_{4}$. The same gas chromatograph with a reduction gas detector (Trace Analytical, RGD-2) was used to analyze CO and $\mathrm{H}_{2}$. A gas chromatograph with an electron capture detector (GC-ECD; Agilent Technologies, HP-6890) was used for $\mathrm{N}_{2} \mathrm{O}$ and $\mathrm{SF}_{6}$ (Machida et al., 2008). The data from the NDIR and gas chromatographs were collected on the same PC. Analytical precisions are better than $0.03 \mathrm{ppm}$ for $\mathrm{CO}_{2}$, $1.7 \mathrm{ppb}$ for $\mathrm{CH}_{4}, 0.3 \mathrm{ppb}$ for $\mathrm{CO}, 3.1 \mathrm{ppb}$ for $\mathrm{H}_{2}, 0.3 \mathrm{ppb}$ for $\mathrm{N}_{2} \mathrm{O}$, and $0.3 \mathrm{ppt}$ for $\mathrm{SF}_{6}$. We prepared two sets of the HSE, so 16 samples were obtained in one flight.

\subsection{Continuous $\mathrm{CO}_{2}$ measurement equipment (CME)}

The CME instrument measures $\mathrm{CO}_{2}$ concentration continuously with a NDIR analyzer (LI-COR, LI-840) during the flight. Figure 2 shows a schematic diagram of the CME installed in the aircraft. The air inlet was placed together with that of the HSE. The air was drawn through the stainless steel tube and pressurized by a diaphragm pump (Gast Manufacturing, Inc., MAA-P108-HB). Sintered filters were inserted to remove fine particles. Prior to the analysis by the NDIR analyzer, the sampled air was dehumidified using a Naflon dryer and a chemical dryer (magnesium perchlorate). The flow rate is kept at 150 standard cc per minute ( $\mathrm{sccm}$ ) by a mass flow controller (HORIBA STEC, Co. Ltd., SEC-E40). The absolute pressure of the NDIR cell was kept constant $(110 \mathrm{hPa})$ by an automatic pressure controller (UR-7340ROB) in the back of the NDIR cell. The inflow of the sampled air to the NDIR cell was switched to two standard gases of $380.89 \mathrm{ppm}$ and $402.44 \mathrm{ppm}$ for $150 \mathrm{~s}$ per $60 \mathrm{~min}$. A programmable controller/data logger device (Campbell Scientific, CR1000) controlled the solenoid valves (Koganei, GA010E1) for switching the introduced gas and monitored measurement parameters, such as flow rate, cell pressure, and so on. Measured $\mathrm{CO}_{2}$ concentrations by the NDIR analyzer were stored every $2 \mathrm{~s}$ in this device and were monitored by a notebook PC through an RS-232C connection. The standard gases were calibrated, before the aircraft measurement, against the $\mathrm{CO}_{2}$ calibration scale at NIES by the gravitational method (NIES95 scale). The NIES95 scale was compared with the World Meteorological Organization Global Atmosphere Watch (WMO GAW) $\mathrm{CO}_{2}$ standard scale at the National Oceanic and Atmospheric Administration's Climate Monitoring and Diagnostic Laboratory (NOAA CMDL) in 1996 (Peterson et al., 1999). The differences in $\mathrm{CO}_{2}$ and $\mathrm{CH}_{4}$ between these scales (NIES-WMO) are 0.10 to $0.14 \mathrm{ppm}$ in a range between 355 and $385 \mathrm{ppm}$ and +4 to $+5 \mathrm{ppb}$ in a range between 1750 and $1838 \mathrm{ppb}$, respectively (Zhou et al., 2009). Switching to two standard gases by regular intervals ( $150 \mathrm{~s}$ per $60 \mathrm{~min}$ ), analytical precision of the CME for the $\mathrm{CO}_{2}$ concentration is within $\pm 0.2 \mathrm{ppm}$ including offset, linearity and drift for $10 \mathrm{~s}$ on average during the aircraft measurements. 


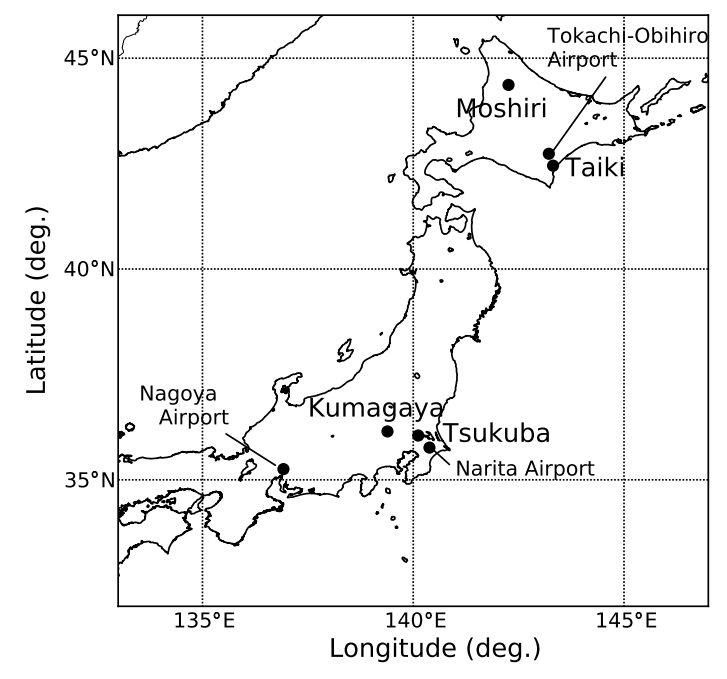

Fig. 3. Observation sites for the present aircraft measurements (Tsukuba, Kumagaya, Moshiri, and Taiki).

\section{Aircraft measurement and ground sites}

The calibration with aircraft vertical profiles is necessary for the g-b FTS measurement to maintain high precision and accuracy. The aircraft measurements were carried out over Tsukuba $\left(36.05^{\circ} \mathrm{N}, 140.12^{\circ} \mathrm{E}\right)$ and Moshiri $\left(44.36^{\circ} \mathrm{N}, 142.26^{\circ} \mathrm{E}\right)$ at around $12: 50 \mathrm{LT}$, which corresponds to GOSAT's overpass time.

The g-b FTSs (Bruker IFS $120 \mathrm{HR}$ ) were operated at both sites. Direct sunlight is introduced into the g-b FTS by a sun tracker and gold-coated mirrors. The g-b FTS measures direct solar spectra in the near-infrared region, and column-averaged abundances of atmospheric constituents are retrieved from the spectra. Measurements with the highresolution g-b FTS are performed according to the TCCON data protocol. A $\mathrm{CaF}_{2}$ beam splitter and an $\mathrm{InGaAs}$ detector are used for the $5500-10500 \mathrm{~cm}^{-1}$ spectral region. A spectral resolution of $0.02 \mathrm{~cm}^{-1}$, aperture size of $0.5 \mathrm{~mm}$, and scanner velocity of $10 \mathrm{kHz}(20 \mathrm{kHz}$ in Moshiri) are used as standard parameters for the TCCON measurements. The pressure in the g-b FTS is kept at $3.9 \times 10^{-2} \mathrm{hPa}$ by an oil-free scroll vacuum pump. The forward- and backwardscanned interferograms are separately integrated over a period of about $70 \mathrm{~s}$.

Vertical profiles of the meteorological parameters (pressure, temperature, relative humidity, wind speed, and wind direction) were measured with radio sondes around the aircraft measurements by the Japan Weather Association under contract with the NIES. Figure 3 shows the location of both observation sites. Tsukuba is $50 \mathrm{~km}$ northeast of Tokyo in the Kanto Plain and includes forests, agricultural lands, and urban areas. Tsukuba is one of the most important sites for validation of GOSAT data, because in addition to the g-b FTS, several instruments are in operation, such as meteorological

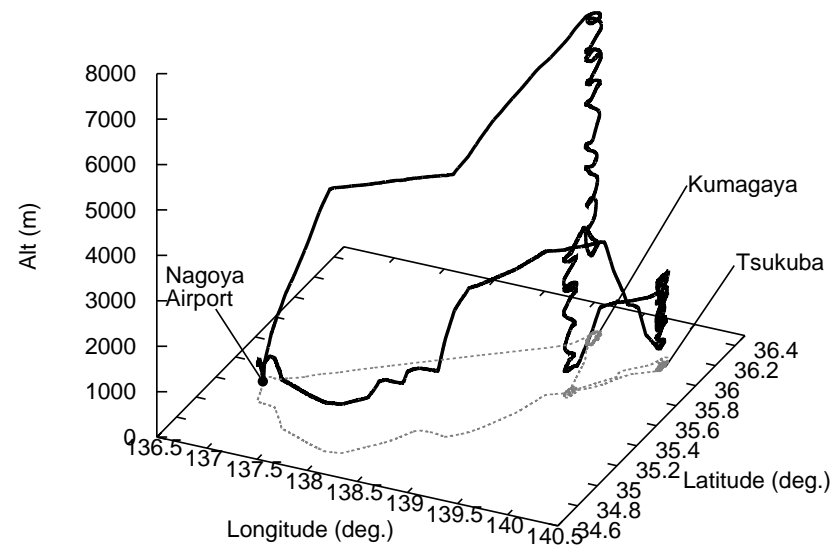

Fig. 4. A flight pattern over Tsukuba performed on 14 February 2010 .

instruments, surface in situ measurements for $\mathrm{CO}_{2}$ and $\mathrm{CH}_{4}$, lidar, and a sky radiometer. $\mathrm{CO}_{2}$ and $\mathrm{CH}_{4}$ concentrations at $1.5,25,100$, and $200 \mathrm{~m}$ altitudes from the ground were continuously observed at the meteorological tower of the Meteorological Research Institute (MRI), Tsukuba, Japan (Inoue and Matsueda, 2001). The Moshiri site is located in a mountainous forest region and can provide validation for GOSAT data recorded over topography different from that of Tsukuba. The flight routes over both sites are described below.

For the flight over Tsukuba, the aircraft took off from Komaki Airport, Aichi, Japan. Air traffic control over Tsukuba is strict because of the controlled airspace for the Narita and Haneda international airports, so the flight over Tsukuba was restricted to altitudes below $2 \mathrm{~km}$. Consequently, the altitudes from $7 \mathrm{~km}$ to $2 \mathrm{~km}$ were sampled over Kumagaya, about $70 \mathrm{~km}$ west of Tsukuba. Vertical profiles measured at Kumagaya were used in the calculation of the total column amounts of $\mathrm{CO}_{2}$ and $\mathrm{CH}_{4}$ at Tsukuba, assuming uniformity of atmospheric concentrations of these compounds in the free troposphere above the planetary boundary layer over Tsukuba and Kumagaya. The typical flight path performed on 14 February 2010 is shown in Fig. 4. It illustrates the spiral descent flights over Tsukuba and Kumagaya.

In August 2009, we also carried out aircraft measurements over Moshiri and Taiki, Hokkaido. Both Moshiri and Taiki were observed on GOSAT's path 5. Tokachi-Obihiro Airport was used as a base camp for the Hokkaido measurements. The aircraft measurements were carried out on $26 \mathrm{Au}-$ gust 2009 over the Moshiri observatory in the Geospace Research Center of the Solar-Terrestrial Environment Laboratory of Nagoya University, which is located in northwestern Hokkaido. The Moshiri observatory, a GOSAT validation observational site, operates a g-b FTS and meteorological instruments.

A descent spiral flight over Taiki was carried out on 30 August 2009 in accordance with a GOSAT measurement. 
Table 1. $\mathrm{X}_{\mathrm{CO}_{2}}$ obtained from the aircraft and the g-b FTS on each observation day over Tsukuba (14, 20, and 23 February) and Moshiri (26 August 2009). The g-b FTS $\mathrm{X}_{\mathrm{CO}_{2}}$ is the average value during the flight. The differences between aircraft $\mathrm{X}_{\mathrm{CO}_{2}}$ and g-b FTS $\mathrm{X}_{\mathrm{CO}_{2}}$ are indicated in the fourth (ppm) and fifth (\%) columns. The average difference and its one standard deviation at the Tsukuba site are indicated in the fifth row. Note that there is no average and one standard deviation of the difference at the Moshiri site.

\begin{tabular}{|c|c|c|c|c|c|}
\hline \multirow{2}{*}{ date } & \multirow{2}{*}{ aircraft ${ }^{*}(\mathrm{ppm})$} & \multirow{2}{*}{ g-b FTS (ppm) } & \multicolumn{2}{|r|}{ difference } & \multirow{2}{*}{ obs. site } \\
\hline & & & g-b FTS-aircraft (ppm) & $(\mathrm{g}-\mathrm{b}$ FTS-aircraft)/aircraft $\times 100(\%)$ & \\
\hline 14 Feb 2010 & 390.70 & 389.91 & -0.80 & -0.20 & \\
\hline 20 Feb 2010 & 391.37 & 389.87 & -1.50 & -0.38 & \\
\hline 23 Feb 2010 & 391.63 & $\begin{array}{l}389.97 \\
\text { Avg. }(1 \sigma)\end{array}$ & $\begin{array}{l}-1.66 \\
-1.32(0.46)\end{array}$ & $\begin{array}{l}-0.42 \\
-0.33(0.11)\end{array}$ & Tsukuba \\
\hline 26 Aug 2009 & 381.574 & 376.851 & -4.72 & -1.24 & Moshiri \\
\hline
\end{tabular}

* The effect of an averaging kernel of the g-b FTS is taken into consideration.

Table 2. $\mathrm{X}_{\mathrm{CO}_{2}}$ obtained from the aircraft and GOSAT (V01.20) on each observation day over Tsukuba (14, 20, and 23 February). The differences between aircraft $\mathrm{X}_{\mathrm{CO}_{2}}$ and GOSAT SWIR $\mathrm{X}_{\mathrm{CO}_{2}}$ are indicated in the fourth (ppm) and fifth (\%) columns. The average difference and its one standard deviation at the Tsukuba site are indicated in the fifth row.

Note that there is no average and one standard deviation of the difference at the Moshiri site.

\begin{tabular}{|c|c|c|c|c|c|}
\hline \multirow{2}{*}{ date } & \multirow{2}{*}{ aircraft (ppm) } & \multirow{2}{*}{ GOSAT (ppm) } & \multicolumn{2}{|r|}{ difference } & \multirow{2}{*}{ obs. site } \\
\hline & & & g-b FTS-aircraft (ppm) & $(\mathrm{g}-\mathrm{b}$ FTS-aircraft)/aircraft $\times 100(\%)$ & \\
\hline 14 Feb 2010 & 391.67 & 372.42 & -19.25 & -4.92 & \\
\hline 20 Feb 2010 & 391.66 & 386.41 & -5.25 & -1.34 & \\
\hline \multirow[t]{2}{*}{23 Feb 2010} & 392.33 & 379.41 & -12.91 & -3.29 & Tsukuba \\
\hline & & Avg. $(1 \sigma)$ & $-12.47(7.01)$ & $-3.18(1.78)$ & \\
\hline
\end{tabular}

Despite the fact that there is no ground observation station at Taiki, located $200 \mathrm{~km}$ southeast of Moshiri, the flatness and homogeneity of its surface improved the GOSAT retrieval algorithm in the initial analysis phase. On 30 August 2009, GOSAT was not successful in retrieving $\mathrm{X}_{\mathrm{CO}_{2}}$ or $\mathrm{X}_{\mathrm{CH}_{4}}$ owing to clouds in its field of view.

We conducted three flights over Tsukuba on 14, 20, and 23 February 2010, and one flight over Moshiri on $30 \mathrm{Au}-$ gust 2009. We obtained four profiles to calculate $\mathrm{X}_{\mathrm{CO}_{2}}$ and $\mathrm{X}_{\mathrm{CH}_{4}}$.

\section{Calculation of $\mathrm{X}_{\mathrm{CO}_{2}}$ and $\mathrm{X}_{\mathrm{CH}_{4}}$ from the aircraft measurement}

To compare the values retrieved from the g-b FTS with those calculated from the aircraft profiles, $\mathrm{CO}_{2}$ and $\mathrm{CH}_{4}$ measured by the aircraft were combined using a priori profiles in GFIT, as described by Wunch et al. (2010). The GFIT algorithm, developed at the Jet Propulsion Laboratory (JPL), is a spectral fitting code for retrieving the column-averaged abundances of atmospheric trace gases from infrared solar absorption spectra (Wunch et al., 2011).

The $\mathrm{CO}_{2}$ a priori profile in GFIT for altitudes up to $10 \mathrm{~km}$ was taken from a climatology based on the GLOBALVIEW dataset (GLOBALVIEW-CO2, 2006), and it varies based on the time of year and the latitude of the site. The stratospheric
$\mathrm{CO}_{2}$ profiles were generated from an age of air relationship derived by Andrews et al. (2001). The GFIT $\mathrm{CH}_{4}$ a priori profiles were generated from balloon-borne MkIV FTS data (Toon, 1991). The $\mathrm{CH}_{4}$ and $\mathrm{HF}$ volume mixing ratios are inversely correlated in the stratosphere (Luo et al., 1995; Washenfelder et al., 2003); therefore, this correlation can be applied to adjust the $\mathrm{CH}_{4}$ profile in the stratosphere. However, since the g-b FTS instruments at Tsukuba and Moshiri do not measure the wavelength window containing the HF absorption, the correction using the $\mathrm{CH}_{4}-\mathrm{HF}$ relationship could not be performed in this study. Instead, we made use of the temperature profile measured by a radio sonde during the aircraft overpasses to determine the difference between the measured tropopause altitude and that calculated in GFIT from the NCEP reanalysis temperature profile, and we adjusted the $\mathrm{CH}_{4}$ stratospheric profile accordingly.

Figures 5 and 6 show combined $\mathrm{CO}_{2}$ and $\mathrm{CH}_{4}$ profiles observed on 20 February 2010 over Tsukuba and Kumagaya. The red and blue dots are the aircraft data and the meteorological tower data at MRI, respectively. The gray lines show the combined ground, aircraft, and GFIT a priori profiles. The errors resulted from the estimated stratospheric profile along with the surface and aircraft measurements, and they were evaluated when the aircraft measurement was integrated using the GFIT a priori stratosphere. The estimated total error is the square root of the sum of squares of these 
Table 3. The same as Table 1, but for $\mathrm{X}_{\mathrm{CH}_{4}}$.

\begin{tabular}{|c|c|c|c|c|c|}
\hline \multirow{2}{*}{ date } & \multirow{2}{*}{$\operatorname{aircraft}^{*}(\mathrm{ppm})$} & \multirow{2}{*}{ FTS (ppm) } & \multicolumn{2}{|r|}{ difference } & \multirow{2}{*}{ obs. site } \\
\hline & & & g-b FTS-aircraft (ppm) & $(\mathrm{g}$-b FTS-aircraft)/aircraft $\times 100(\%)$ & \\
\hline 14 Feb 2010 & 1.8023 & 1.7961 & -0.0062 & -0.34 & \\
\hline 20 Feb 2010 & 1.8066 & 1.7908 & -0.0158 & -0.88 & \\
\hline 23 Feb 2010 & 1.8045 & 1.7887 & -0.0158 & -0.88 & Tsukuba \\
\hline & & Avg. diff. $(1 \sigma)$ & $-0.0126(0.0055)$ & $-0.69(0.29)$ & \\
\hline 26 Aug 2009 & 1.7943 & 1.7565 & -0.0378 & -2.11 & Moshiri \\
\hline
\end{tabular}

* The effect of an averaging kernel of the g-b FTS is taken into consideration.

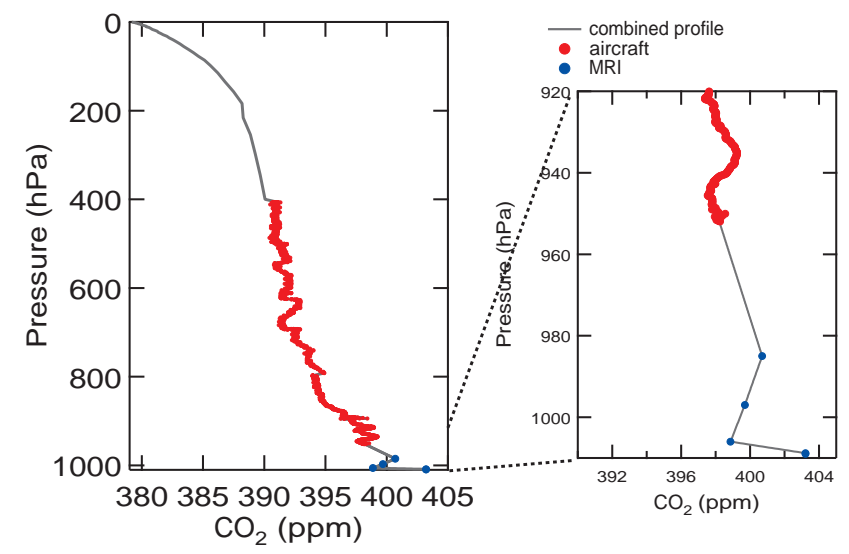

Fig. 5. Combined $\mathrm{CO}_{2}$ profile observed on 20 February 2010 over Tsukuba and Kumagaya. Red and blue dots are the aircraft (in situ) data and the meteorological tower data of the Meteorological Research Institute (MRI), respectively. The gray lines show the combined ground, aircraft, and GFIT a priori profiles.

components. We estimated a total error of $0.5 \mathrm{ppm}$ for $\mathrm{CO}_{2}$ and $9 \mathrm{ppb}$ for $\mathrm{CH}_{4}$ in the same manner as in the TCCON calibration.

For comparisons of $\mathrm{X}_{\mathrm{CO}_{2}}$ and $\mathrm{X}_{\mathrm{CH}_{4}}$ from aircraft profiles with those retrieved from the g-b FTS, averaging kernels of the g-b FTS measurements must be taken into account. The $\mathrm{X}_{\mathrm{CO}_{2}}$ for the aircraft in situ profile weighted by the columnaveraging kernel $a$ (Rodgers and Connor, 2003) is calculated as follows:

$\mathrm{X}_{\mathrm{CO}_{2}}^{\mathrm{insitu}}=\mathrm{X}_{\mathrm{CO}_{2}}^{\mathrm{a}}+\sum_{j} h_{j} a_{j}\left(t_{\text {in situ }}-t_{\mathrm{a}}\right)_{j}$

where $\mathrm{X}_{\mathrm{CO}_{2}}^{\mathrm{a}}$ is the column-averaged dry mole fraction for the a priori profile $t_{\mathrm{a}}, h_{j}$ is the pressure weighting function, and $t_{\text {in situ }}$ is the in situ profile from the aircraft measurement. The column-averaging kernels for the g-b FTSs at Tsukuba and Moshiri are shown in Fig. 7. Column-averaging kernels vary as a function of pressure and solar zenith angle. The $\mathrm{X}_{\mathrm{CH}_{4}}$ is derived in the same way using Eq. (1). The column-averaging kernel $a$ for the g-b FTS is used in Tables 1 and 3. Another column-averaging kernel $a$ for GOSAT is used in Tables 2 and 4 .

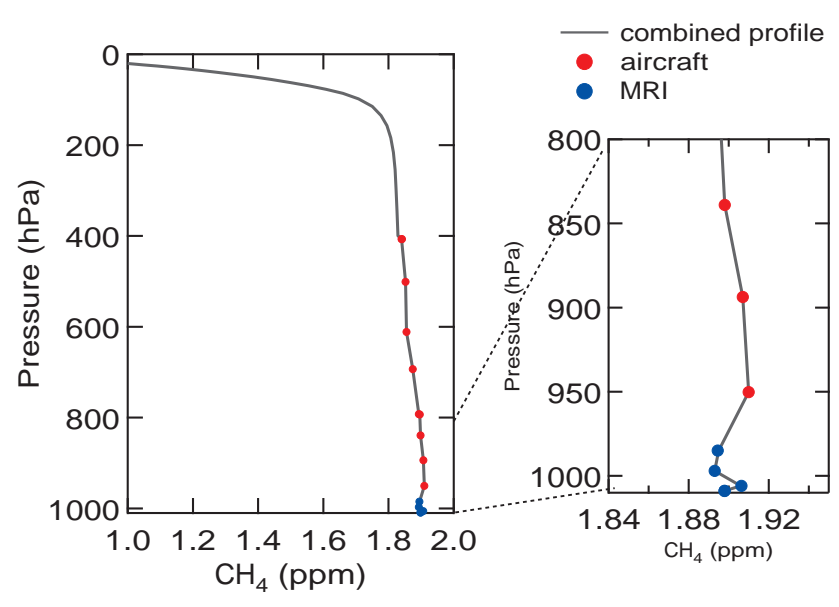

Fig. 6. The same as Fig. 5, but for $\mathrm{CH}_{4}$. The aircraft data shown are from the flask-sampling air.

\section{Results and discussion}

\subsection{Comparison of the g-b FTSs and GOSAT with the aircraft measurement}

The $\mathrm{X}_{\mathrm{CO}_{2}}$ and $\mathrm{X}_{\mathrm{CH}_{4}}$ values retrieved from the g-b FTS measurements at Tsukuba (February 2010) and Moshiri (August 2009) were compared with those calculated from the aircraft measurements. The g-b FTS data were corrected for an airmass-dependent artifact for $\mathrm{X}_{\mathrm{CO}_{2}}$ and were calibrated with the TCCON common scaling factors empirically determined using aircraft profiles over many TCCON sites to place the TCCON data on the WMO standard reference scales (Wunch et al., 2010) for $\mathrm{X}_{\mathrm{CO}_{2}}$ and $\mathrm{X}_{\mathrm{CH}_{4}}$. The GOSAT data (V01.20) were successfully retrieved over Tsukuba on 14, 20, and 23 February 2010, when the aircraft measurements were carried out. There are two types of GOSAT data: those for Research Announcement investigators (RA) and for general public users (GU). GU data are selected from RA data based on several criteria. The degrees of freedom for signals must be larger than unity, the mean squares of the residual spectra must be less than 3 or the chi-square for the retrieval state must be less than 5, and aerosol optical thickness (AOT) at $1600 \mathrm{~nm}$ must be less than 0.5 (Yoshida et al., 2011). The 
Table 4. The same as Table 2, but for $\mathrm{X}_{\mathrm{CH}_{4}}$.

\begin{tabular}{cccll}
\hline \multirow{2}{*}{ date } & aircraft* $(\mathrm{ppm})$ & GOSAT $(\mathrm{ppm})$ & \multicolumn{2}{c}{ difference } \\
\cline { 4 - 5 } & & & g-b FTS-aircraft $(\mathrm{ppm})$ & $(\mathrm{g}$-b FTS-aircraft)/aircraft $\times 100(\%)$ \\
\hline 14 Feb 2010 & 1.8122 & 1.7504 & -0.0618 & -3.41 \\
20 Feb 2010 & 1.8110 & 1.7796 & -0.0313 & -1.73 \\
23 Feb 2010 & 1.8150 & 1.7671 & -0.0479 & -2.64 \\
& & Avg. diff. $(1 \sigma)$ & $-0.0470(0.0152)$ & $-2.59(0.84)$ \\
\hline
\end{tabular}

* The effect of an averaging kernel of the GOSAT is taken into consideration.

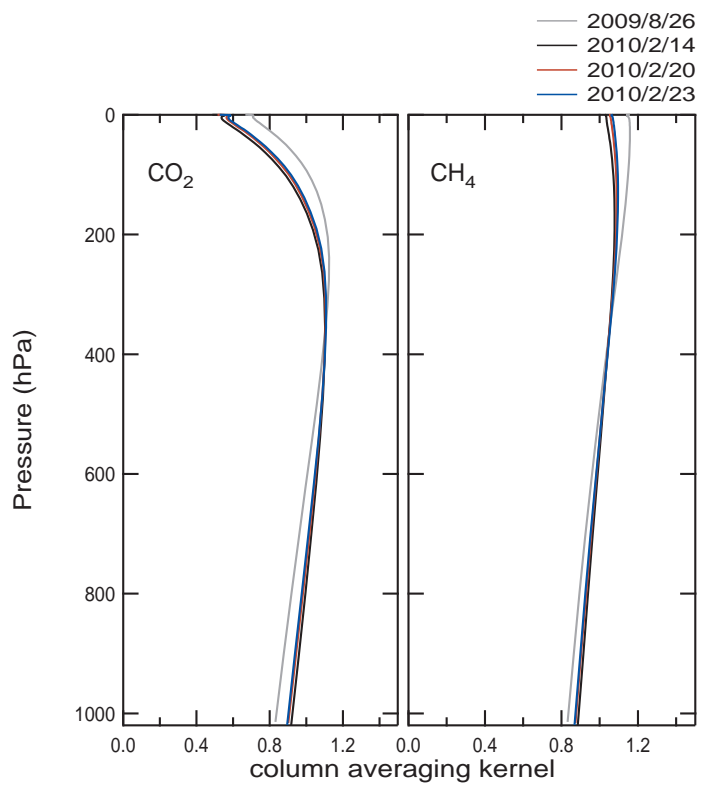

Fig. 7. Column-averaging kernels for g-b FTS at Tsukuba and Moshiri.

GOSAT data on 14 February 2010 are released only for RA. The time series of the g-b FTS $\mathrm{X}_{\mathrm{CO}_{2}}$ and $\mathrm{X}_{\mathrm{CH}_{4}}$ at Tsukuba are shown in Figs. 8 and 9 with the aircraft and the GOSAT data. Figure 10 shows the time series of the g-b FTS $\mathrm{X}_{\mathrm{CO}_{2}}$ and $\mathrm{X}_{\mathrm{CH}_{4}}$ at Moshiri. The differences of $\mathrm{X}_{\mathrm{CO}_{2}}$ and $\mathrm{X}_{\mathrm{CH}_{4}}$ values from the g-b FTS and GOSAT to those calculated from the aircraft measurements are summarized in Tables 1 to 4 . The $\mathrm{X}_{\mathrm{CO}_{2}}$ and $\mathrm{X}_{\mathrm{CH}_{4}}$ values from the aircraft measurements were calculated taking the averaging kernels of the g-b FTS and GOSAT into account. Detailed results on $\mathrm{X}_{\mathrm{CO}_{2}}$ and $\mathrm{X}_{\mathrm{CH}_{4}}$ are described in the next subsections.

\section{$5.2 \quad \mathrm{X}_{\mathrm{CO}_{2}}$}

Figure 8 shows the time series of the g-b FTS $\mathrm{X}_{\mathrm{CO}_{2}}$ over Tsukuba along with the aircraft and GOSAT $\mathrm{X}_{\mathrm{CO}_{2}}$. Retrieved $\mathrm{g}$-b FTS data were filtered using the fractional variation in solar intensity (FVSI) during a measurement measured by a pyranometer. The average values of the g-b FTS during the flight over Tsukuba are indicated at the intermediate times
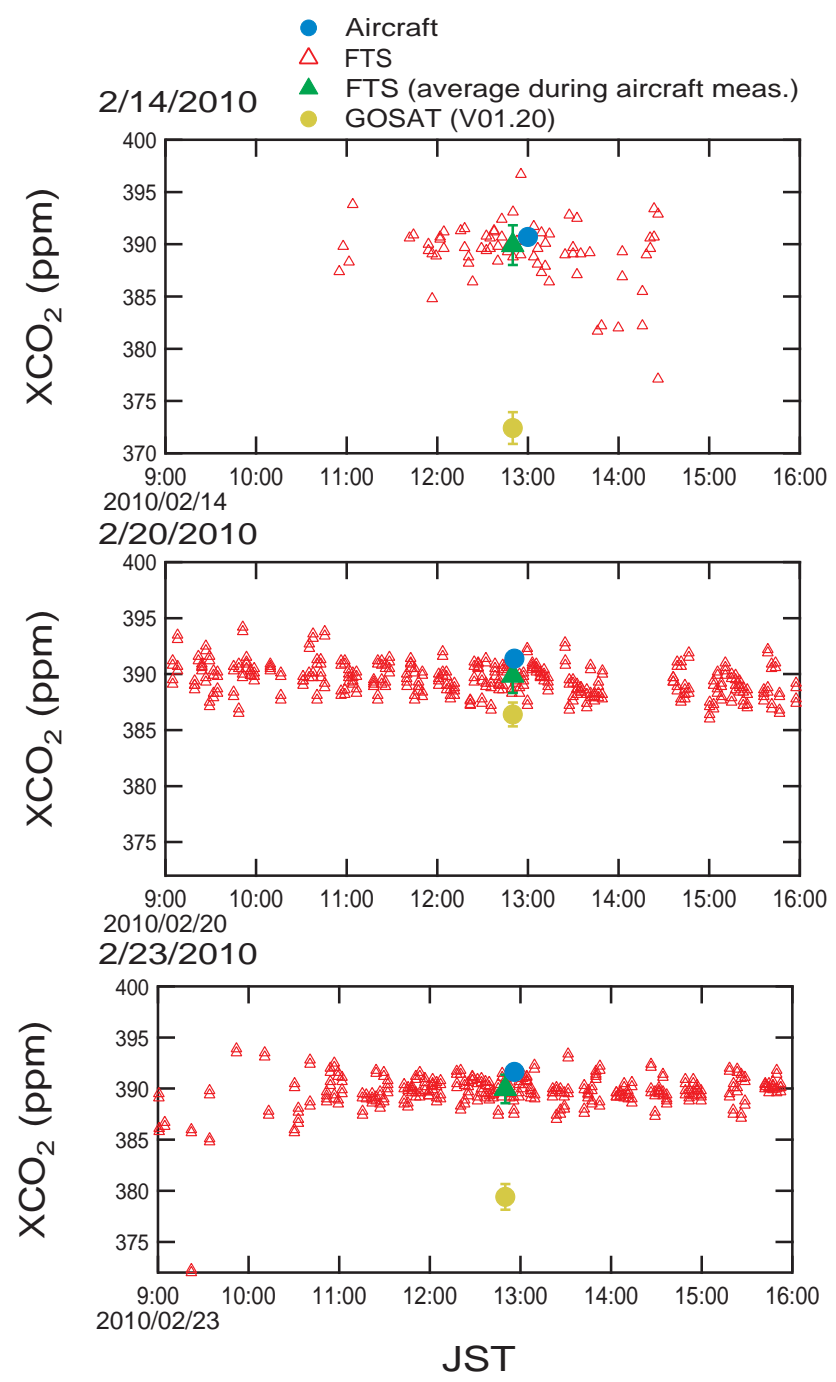

Fig. 8. The time series of the g-b FTS $\mathrm{X}_{\mathrm{CO}_{2}}$ are shown together with the aircraft and the GOSAT SWIR (V01.20) data on each observation day. The GOSAT data on 14 February 2010 are released only for RA. The average values of the g-b FTS during the flight over Tsukuba are indicated at the intermediate flight times. GOSAT $\mathrm{X}_{\mathrm{CO}_{2}}$ are biased low by $8.85 \mathrm{ppm}$, reported by Morino et al. (2011). 


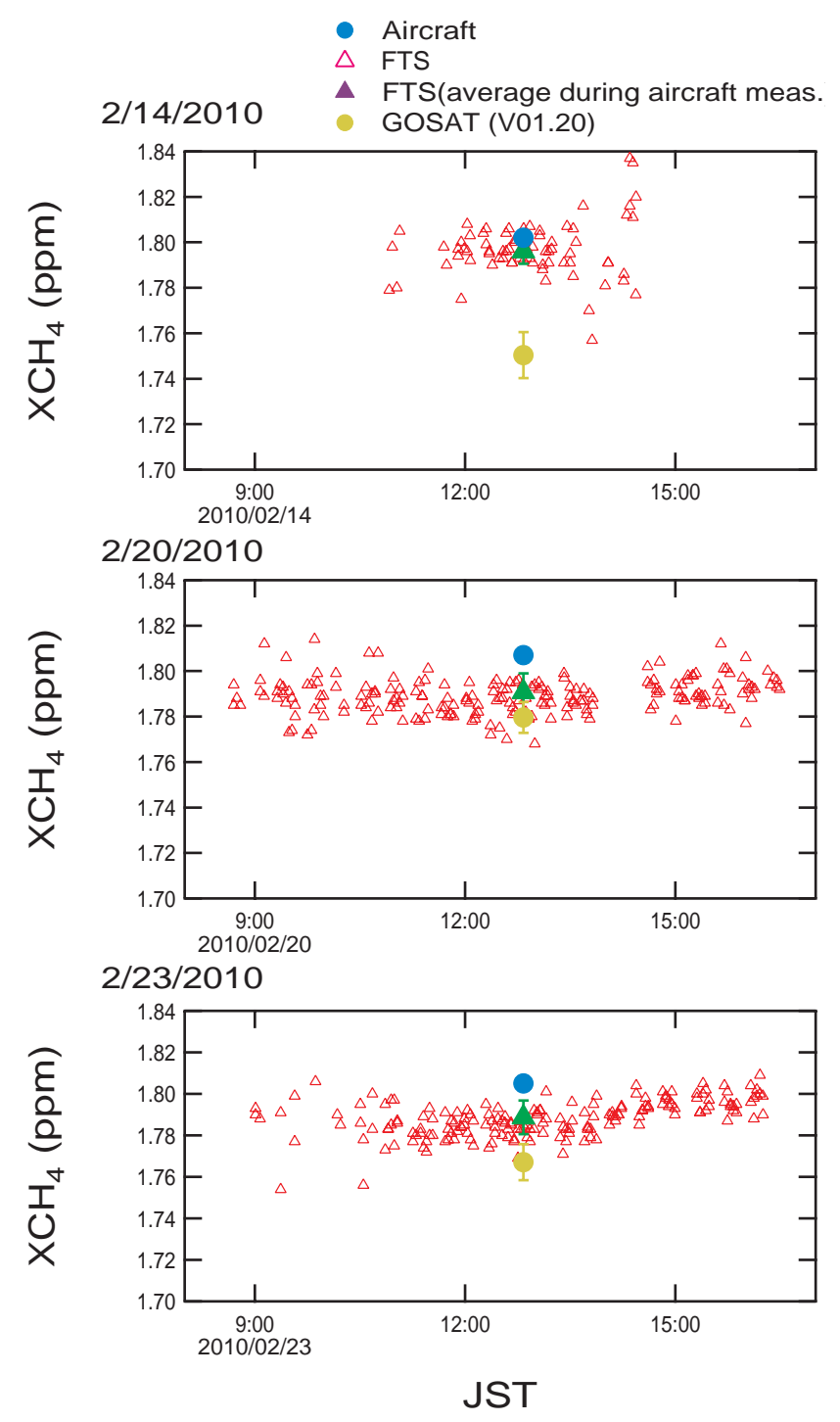

Fig. 9. The same as Fig. 8, but for $\mathrm{X}_{\mathrm{CH}_{4}}$. GOSAT $\mathrm{X}_{\mathrm{CH}_{4}}$ are biased low by $20.4 \mathrm{ppb}$, reported by Morino et al. (2011).

of the flights as shown in Fig. 8. On 20 and 23 February, weather conditions were optimal for direct solar measurement. In contrast, on 14 February, they were not optimal because the sky was partially cloudy. Table 1 summarizes the values of $\mathrm{X}_{\mathrm{CO}_{2}}$ from the aircraft and the g-b FTS and the differences of $\mathrm{X}_{\mathrm{CO}_{2}}$ between the aircraft and the g-b FTS for Tsukuba and Moshiri. The g-b FTS $\mathrm{X}_{\mathrm{CO}_{2}}$ values at Tsukuba are slightly biased low compared to the aircraft $\mathrm{X}_{\mathrm{CO}_{2}}$ values, as listed in Table 1 . The average difference between the g-b FTS $\mathrm{X}_{\mathrm{CO}_{2}}$ and the aircraft $\mathrm{X}_{\mathrm{CO}_{2}}$ with one standard deviation for the Tsukuba site is $1.32 \pm 0.46 \mathrm{ppm}$, which corresponds to $0.33 \pm 0.11 \%$. This small bias between the Tsukuba (g-b) FTS and the aircraft $\mathrm{X}_{\mathrm{CO}_{2}}$ remains even after the standard TCCON calibration described in detail in Wunch et al. (2010) and might be due to the effect of ghosts, artificial spectra that

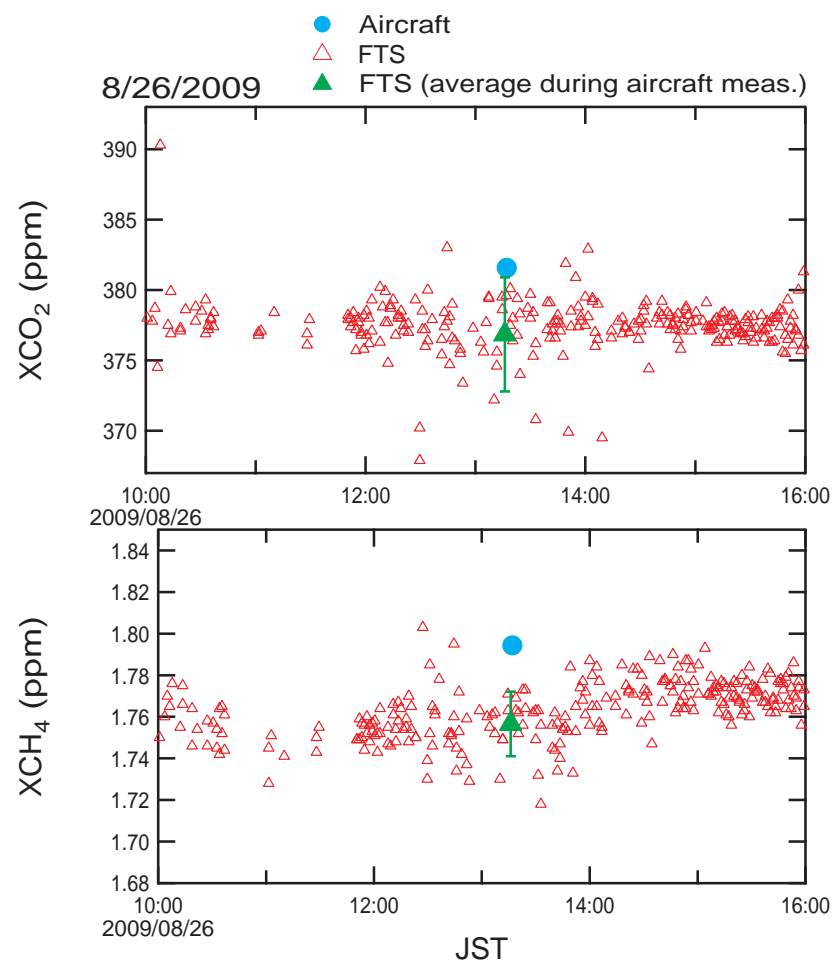

Fig. 10. The time series of the g-b FTS $\mathrm{X}_{\mathrm{CO}_{2}}$ and $\mathrm{X}_{\mathrm{CH}_{4}}$ at Moshiri are shown together with the aircraft data on 26 August 2009.

are mirror images of the original spectra, caused by $\mathrm{He}-\mathrm{Ne}$ laser mis-sampling (Messerschmidt et al., 2010) or of improperly fitting the instrument line shape.

Though the GOSAT SWIR $\mathrm{X}_{\mathrm{CO}_{2}}$ values are relatively low compared with those of the aircraft, as listed in Table 2, this is consistent with the result using GU data reported by Morino et al. (2011) that the GOSAT SWIR $\mathrm{X}_{\mathrm{CO}_{2}}$ is biased low by $8.85 \pm 4.75 \mathrm{ppm}$. The differences at Tsukuba in February 2010 are within the value reported by Morino et al. (2011) except for the value on 14 February, which is released only for RA. On 14 February, thin cirrus clouds were measured at around $11 \mathrm{~km}$ using lidar, indicating that the $\mathrm{X}_{\mathrm{CO}_{2}}$ and $\mathrm{X}_{\mathrm{CH}_{4}}$ data retrieved by GOSAT SWIR were contaminated by the clouds (Uchino et al., 2012). These cirrus clouds give rise to a difference between the actual optical path and the assumed optical path, which affected the GOSAT SWIR retrieval.

At Moshiri, the g-b FTS had a significant low bias and large variance during flight compared with the result obtained over Tsukuba, as shown in Fig. 10. It is likely that there were clouds in the field of view of the g-b FTS during measurement at Moshiri, but it was difficult to screen retrieved $\mathrm{X}_{\mathrm{CO}_{2}}$ values by the FVSI because the temporal resolution of the pyranometer recording is $1 \mathrm{~min}$ and the scan time for the g-b FTS is less than $1 \mathrm{~min}$. The faster scan speed $(20 \mathrm{kHz})$ of the g-b FTS at Moshiri compared to the TCCON norm decreased the signal-to-noise ratio of the 
measured spectra. Currently, the pyranometer measures every $2 \mathrm{~s}$, matching the pyranometer measurement frequency at Tsukuba, and screening by FVSI is possible, so we anticipate a reduction in the uncertainties of $\mathrm{X}_{\mathrm{CO}_{2}}$ and $\mathrm{X}_{\mathrm{CH}_{4}}$ in the future.

\section{$5.3 \quad \mathrm{X}_{\mathrm{CH}_{4}}$}

The time series of the g-b FTS $\mathrm{X}_{\mathrm{CH}_{4}}$ over Tsukuba are shown in Fig. 9 along with the aircraft and GOSAT values. Table 3 shows the values of $\mathrm{X}_{\mathrm{CH}_{4}}$ measured by the aircraft and g-b FTS, and the differences of the g-b FTS data to the aircraft data for Tsukuba and Moshiri. The average difference of the g-b FTS $\mathrm{X}_{\mathrm{CH}_{4}}$ data to the aircraft $\mathrm{X}_{\mathrm{CH}_{4}}$ data is $12.6 \pm 5.5 \mathrm{ppb}$, which corresponds to $0.69 \pm 0.29 \%$, for Tsukuba. For $\mathrm{X}_{\mathrm{CH}_{4}}$, the uncertainty was larger than that of TCCON calibration. This is partly because the compensation by the $\mathrm{CH}_{4}-\mathrm{HF}$ correlation was not carried out as mentioned in Sect. 4. In the TCCON calibration, the average and maximum adjustments by the $\mathrm{CH}_{4}-\mathrm{HF}$ correlation are $0.4 \mathrm{~km}$ and $1.8 \mathrm{~km}$ in altitude, respectively (Wunch et al., 2010). As a result of the adjustment of $\mathrm{CH}_{4}$ concentration, the average adjustment of $0.4 \mathrm{~km}$ produces a difference within $3 \mathrm{ppb}$ $(0.2 \%)$ in the amount of column in our case. Differences from $-16 \mathrm{ppb}$ to $13 \mathrm{ppb}$ (from $-0.9 \%$ to $0.7 \%$ ) appeared in the maximum adjustment of $1.8 \mathrm{~km}$ and can partly explain the discrepancy with the TCCON calibration. In this observation, the tropopause height can be determined from meteorological parameters measured by radio sondes. Comparing the differences of the true tropopause heights with those assumed in the GFIT algorithm for 14, 20, 23 February, and 26 August are $-100 \mathrm{~m}, 200 \mathrm{~m},-500 \mathrm{~m}$, and $200 \mathrm{~m}$, which corresponds to $-0.8,1.9,-4.4$, and $1.8 \mathrm{ppb}$, respectively. Comparing the aircraft $\mathrm{X}_{\mathrm{CH}_{4}}$ with GOSAT $\mathrm{X}_{\mathrm{CH}_{4}}$ over Tsukuba, as listed in Table 4, the GOSAT data had slightly larger differences compared with the results reported by Morino et al. (2011). The relatively large low bias due to the influence of the cirrus clouds was also seen in $\mathrm{X}_{\mathrm{CO}_{2}}$ on 14 February 2010.

At Moshiri, the difference between the aircraft and the g-b FTS $\mathrm{X}_{\mathrm{CH}_{4}}$ was large compared with the result obtained at Tsukuba because of the same reasons explained for $\mathrm{X}_{\mathrm{CO}_{2}}$.

\section{Conclusions}

Aircraft measurements were conducted over Tsukuba and Moshiri for the calibration of the $\mathrm{g}-\mathrm{b}$ FTSs and the validation of GOSAT. In the February 2010 flights over Tsukuba, we succeeded in performing simultaneous observations of the (g-b) FTS, the aircraft in situ and flask-sampling instruments, and GOSAT.

Retrieved $\mathrm{X}_{\mathrm{CO}_{2}}$ and $\mathrm{X}_{\mathrm{CH}_{4}}$ values from the g-b FTS measurements show good agreement with the aircraft measurements over Tsukuba. Contrarily, the negative biases in $\mathrm{X}_{\mathrm{CO}_{2}}$ and $\mathrm{X}_{\mathrm{CH}_{4}}$ measured by the g-b FTS were relatively large over Moshiri compared with those over Tsukuba. This was probably due to the lack of screening by the FVSI and the higher scan speed of the g-b FTS.

The GOSAT data underestimate both $\mathrm{X}_{\mathrm{CO}_{2}}$ and $\mathrm{X}_{\mathrm{CH}_{4}}$ compared to the aircraft measurements. The average differences of GOSAT SWIR $\mathrm{X}_{\mathrm{CO}_{2}}$ and $\mathrm{X}_{\mathrm{CH}_{4}}$ compared to the aircraft $\mathrm{X}_{\mathrm{CO}_{2}}$ and $\mathrm{X}_{\mathrm{CH}_{4}}$ were $9.08 \pm 5.41 \mathrm{ppm}(2.31 \pm 1.37 \%)$ for $\mathrm{X}_{\mathrm{CO}_{2}}$ and $39 \pm 11 \mathrm{ppb}(2.18 \pm 0.64 \%)$ for $\mathrm{X}_{\mathrm{CH}_{4}}$ excluding the cloudy GOSAT data of 14 February 2010 . These average differences are consistent with the preliminary results of GOSAT validation efforts (Morino et al., 2011). The comparisons of the g-b FTS and GOSAT with the aircraft measurement show that the effects of contributing factors such as aerosols and thin cirrus clouds on the retrieval from GOSAT are not negligible. Further validation experiments using instruments with a combination of g-b FTS, aircraft, observation tower, lidar, and sky radiometer are necessary to improve the retrieval algorithm for GOSAT and decrease uncertainties of the GOSAT SWIR $\mathrm{X}_{\mathrm{CO}_{2}}$ and $\mathrm{X}_{\mathrm{CH}_{4}}$ data.

Acknowledgements. We are deeply grateful to the NIES GOSAT project members for their useful comments. This work was financially supported by the Ministry of the Environment, which made completing this study possible.

Edited by: D. Feist

\section{References}

Andrews, A. E., Boering, K. A., Daube, B. C., Wofsy, S. C., Jost, M. L. H., Podolske, J. R., Webster, C. R., Herman, R. L., Scott, D. C., Flesch, G. J., Moyer, E. J., Elkins, J. W., Dutton, G. S., Hurst, D. F., Moore, F. L., Ray, E. A., Romashkin, P. A., and Strahan, S. E.: Mean ages of stratospheric air derived from in situ observations of $\mathrm{CO}_{2}, \mathrm{CH}_{4}$, and $\mathrm{N}_{2} \mathrm{O}$, J. Geophys. Res., 106, 32295-32314, 2001.

GLOBALVIEW-CO2: Cooperative Atmospheric Data Integration Project - Carbon Dioxide. CD-ROM, NOAA ESRL, Boulder, Colorado, also available on Internet via anonymous FTP to ftp.cmdl.noaa.gov, last access: August 2011, Path: ccg/co2/GLOBALVIEW, 2006.

Gurney, K. R., Law, R. M., Denning, A. S., Rayner, P. J., Baker, D., Bousquet, P., Bruhwiler, L., Chen, Y.-H., Ciais, P., Fan, S., Fung, I. Y., Gloor, M., Heimann, M., Higuchi, K., John, J., Maki, T., Maksyutov, S., Masarie, K., Peylin, P., Prather, M., Pak, B. C., Randerson, J., Sarmiento, J., Taguchi, S., Takahashi, T., and Yuen, C.-W.: Towards robust regional estimates of $\mathrm{CO}_{2}$ sources and sinks using atmospheric transport models, Nature, 415, 626630, doi:10.1038/415626a, 2001.

Inoue, $\mathrm{H}$. Y. and Matsueda, $\mathrm{H}$.: Measurements of atmospheric $\mathrm{CO}_{2}$ from a meteorological tower in Tsukuba, Japan, Tellus B, 53, 205-219, 2001.

Kuze, A., Suto, H., Nakajima, M., and Hamazaki, T.: Thermal and near infrared sensor for carbon observation Fourier-transform spectrometer on the Greenhouse Gases Observing Satellite for 
greenhouse gases monitoring, Appl. Optics, 48, 6716-6733, 2009.

Luo, M., Cicerone, R. J., and Russell III, J. M..: Analysis of Halogen Occultation Experiment $\mathrm{HF}$ versus $\mathrm{CH}_{4}$ correlation plots: Chemistry and transport implications, J. Geophys. Res., 100, 1392713937, 1995.

Machida, T., Matsueda, H., Sawa, Y., Nakagawa, Y., Hirotani, K., Kondo, N., Goto, K., Nakazawa, T., Ishikawa, K., and Ogawa, T.: Worldwide Measurements of Atmospheric $\mathrm{CO}_{2}$ and Other Trace Gas Species Using Commercial Airlines, J. Atmos. Ocean. Tech., 25, 1744-1754, doi:10.1175/2008JTECHA1082.1, 2008.

Mao, J. and Kawa, S. R.: Sensitivity studies for spacebased measurement of atmospheric total column carbon dioxide by reflected sunlight, App. Optics, 5, 914-927, doi:10.1029/2001JD000617, 2004.

Messerschmidt, J., Macatangay, R., Notholt, J., Petri, C., Warneke, T., and Weinzierl, C.: Side by side measurements of $\mathrm{CO}_{2}$ by ground-based Fourier transform spectrometry (FTS), Tellus B, 62, 749-758, doi:10.1111/j.1600-0889.2010.00491.x, 2010.

Messerschmidt, J., Geibel, M. C., Blumenstock, T., Chen, H., Deutscher, N. M., Engel, A., Feist, D. G., Gerbig, C., Gisi, M., Hase, F., Katrynski, K., Kolle, O., Lavric, J. V., Notholt, J., Palm, M., Ramonet, M., Rettinger, M., Schmidt, M., Sussmann, R., Toon, G. C., Truong, F., Warneke, T., Wennberg, P. O., Wunch, D., and Xueref-Remy, I.: Calibration of TCCON column-averaged $\mathrm{CO}_{2}$ : the first aircraft campaign over European TCCON sites, Atmos. Chem. Phys., 11, 10765-10777, doi:10.5194/acp-11-10765-2011, 2011.

Morino, I., Uchino, O., Inoue, M., Yoshida, Y., Yokota, T., Wennberg, P. O., Toon, G. C., Wunch, D., Roehl, C. M., Notholt, J., Warneke, T., Messerschmidt, J., Griffith, D. W. T., Deutscher, N. M., Sherlock, V., Connor, B., Robinson, J., Sussmann, R., and Rettinger, M.: Preliminary validation of column-averaged volume mixing ratios of carbon dioxide and methane retrieved from GOSAT short-wavelength infrared spectra, Atmos. Meas. Tech., 4, 1061-1076, doi:10.5194/amt-4-1061-2011, 2011.

O'Brien, D. M. and Rayner, P. J.: Global observations of the carbon budget 2. $\mathrm{CO}_{2}$ column from differential absorption of reflected sunlight in the $1.61 \mu \mathrm{m}$ band of $\mathrm{CO}_{2}$, J. Geophys. Res., 5, 4354, doi:10.1029/2001JD000617, 2002.

Ohyama, H., Morino, I., Nagahama, T., Machida, T., Suto, H., Oguma, H., Sawa, Y., Matsueda, H., Sugimoto, N., Nakane, H., and Nakagawa, K.: Column-averaged volume mixing ratio of $\mathrm{CO}_{2}$ measured with ground-based Fourier transform spectrometer at Tsukuba, J. Geophys. Res., 114, D18303, doi:10.1029/2008JD011465, 2009.

Peterson, J., Tans, P., and Kitzis, D.: $\mathrm{CO}_{2}$ Round-robin Reference Gas Intercomparison, in: Report of the Ninth WMO Meeting of Experts on Carbon Dioxide Concentration and Related Tracer Measurement Techniques, edited by: Francey, R., World Meteorological Organization, Geneva, Swizerland, 1999.

Rayner, P. J. and O'Brien, D. M.: The utility of remotely sensed $\mathrm{CO}_{2}$ concentration data in surface source inversions, Geophys. Res. Lett., 28, 175-178, 2001.
Rodgers, C. D. and Connor, B. J.: Intercomparison of remote sounding instruments, J. Geophys. Res., 108, 4116, doi:10.1029/2002JD002299, 2003.

Toon, G.: The JPL MkIV interferometer, Opt. Photon. News, 2, 1921, 1991.

Uchino, O., Kikuchi, N., Sakai, T., Morino, I., Yoshida, Y., Nagai, T., Shimizu, A., Shibata, T., Yamazaki, A., Uchiyama, A., Kikuchi, N., Oshchepkov, S., Bril, A., and Yokota, T.: Influence of aerosols and thin cirrus clouds on the GOSAT-observed $\mathrm{CO}_{2}$ : a case study over Tsukuba, Atmos. Chem. Phys., 12, 3393-3404, doi:10.5194/acp-12-3393-2012, 2012.

Washenfelder, R. A., Wennberg, P. O., and Toon, G. C.: Tropospheric methane retrieved from ground-based near-IR solar absorption spectra, Geophys. Res. Lett., 30, 2226, doi:10.1029/2003GL017969, 2003.

Winderlich, J., Chen, H., Gerbig, C., Seifert, T., Kolle, O., Lavric, J. V., Kaiser, C., Höfer, A., and Heimann, M.: Continuous lowmaintenance $\mathrm{CO}_{2} / \mathrm{CH}_{4} / \mathrm{H}_{2} \mathrm{O}$ measurements at the Zotino Tall Tower Observatory (ZOTTO) in Central Siberia, Atmos. Meas. Tech., 3, 1113-1128, doi:10.5194/amt-3-1113-2010, 2010.

WMO2011: WMO Greenhouse Gas Bulletin, NO. 7, available at http://www.wmo.int/pages/prog/arep/gaw/ghg/GHGbulletin. html (last access: March 2012), 2011.

Wunch, D., Toon, G. C., Wennberg, P. O., Wofsy, S. C., Stephens, B. B., Fischer, M. L., Uchino, O., Abshire, J. B., Bernath, P., Biraud, S. C., Blavier, J.-F. L., Boone, C., Bowman, K. P., Browell, E. V., Campos, T., Connor, B. J., Daube, B. C., Deutscher, N. M., Diao, M., Elkins, J. W., Gerbig, C., Gottlieb, E., Griffith, D. W. T., Hurst, D. F., Jiménez, R., Keppel-Aleks, G., Kort, E. A., Macatangay, R., Machida, T., Matsueda, H., Moore, F., Morino, I., Park, S., Robinson, J., Roehl, C. M., Sawa, Y., Sherlock, V., Sweeney, C., Tanaka, T., and Zondlo, M. A.: Calibration of the Total Carbon Column Observing Network using aircraft profile data, Atmos. Meas. Tech., 3, 1351-1362, doi:10.5194/amt3-1351-2010, 2010.

Wunch, D., Toon, G. C., Blavier, J.-F. L., Washenfelder, R. A., Notholt, J., Connor, B. J., Griffith, D. W. T., Sherlock, V., and Wennberg, P. O.: The Total Carbon Column Observing Network (TCCON), Philos. T. Roy. Soc. A, 369, 2087-2112, doi:10.1098/rsta.2010.0240, 2011.

Yokota, T., Yoshida, Y., Eguchi, N., Ota, Y., Tanaka, T., Watanabe, H., and Maksyutov, S.: Global Concentrations of $\mathrm{CO}_{2}$ and $\mathrm{CH}_{4}$ Retrieved from GOSAT: First Preliminary Results, SOLA, 5, 160-163, doi:10.2151/sola.2009-041, 2009.

Yoshida, Y., Ota, Y., Eguchi, N., Kikuchi, N., Nobuta, K., Tran, H., Morino, I., and Yokota, T.: Retrieval algorithm for $\mathrm{CO}_{2}$ and $\mathrm{CH}_{4}$ column abundances from short-wavelength infrared spectral observations by the Greenhouse gases observing satellite, Atmos. Meas. Tech., 4, 717-734, doi:10.5194/amt-4-717-2011, 2011.

Zhou, L. X., Kitzis, D., and Tans, P. P.: Report of the fourth WMO Round-Robin reference gas intercomparison, 2002-2007, in: Report of the 14th WMO Meeting of Experts on Carbon Dioxide Concentration and Related Tracer Measurement Techniques, edited by: Laurila, T., Helsinki, Finland, 40-43, 2009. 